\title{
Remittances and Economic Growth in Mexico: An Empirical Study with Structural Breaks, 1970-2010
}

\author{
Miguel D. Ramirez \\ Trinity College, Hartford, CT, USA \\ Tel: 860-297-2487Ｅ-mail: miguel.ramirez@trincoll.edu
}

Received: April 12, 2014 Accepted: May 18, 2014

doi:10.5296/ber.v4i1.5712 URL: http://dx.doi.org/10.5296/ber.v4i1.5712

\begin{abstract}
This paper investigates remittance flows to Mexico during the 1980-2010 period in absolute terms, relative to GDP, in comparison to FDI inflows, and in terms of their regional destination. Next, the paper reviews the growing literature that assesses the impact of remittances on investment spending and economic growth. Third, it presents a simple endogenous growth model that explicitly incorporates the potential impact of remittance flows on economic and labor productivity growth. Fourth, it presents a modified empirical counterpart to the simple model that tests for both single- and two-break unit root tests, as well as performs cointegration tests with an endogenously determined level shift over the 1970-2010 period. The error-correction model estimates suggest that remittance flows to Mexico have a positive and significant effect, albeit small, on both economic growth and labor productivity growth. The concluding section summarizes the major results and discusses potential avenues for future research on this important topic.
\end{abstract}

Keywords: Error-correction model, FDI inflows, Gregory-Hansen cointegration single-break test, Gross fixed capital formation, Johansen Cointegration test, KPSS no unit root test, Lee-Strazicich two-break unit root test, remittance flows, and Zivot-Andrews single-break unit root test.

JEL: C10, F01, 04, 010 and 054

\section{Introduction}

Over the past decade or so, remittance flows to Latin America and the Caribbean in general, and Mexico in particular, have increased dramatically, even surpassing their FDI inflows for selected years. Figure 1 below shows that remittance flows to Latin America and the Caribbean increased steadily from US $\$ 21.3$ bn in 2001 to US $\$ 53$ bn in 2005 , before jumping to US $\$ 61.5$ bn in 2006 and almost US\$70 bn in 2008. The figure also reveals that the onset of the Great 


\section{Macrothink}

Business and Economic Research

ISSN 2162-4860

2014, Vol. 4, No. 1

Recession in 2008-09 led to a significant reduction in these flows before leveling off in 2010 and moving upward to an estimated $\$ 62 \mathrm{bn}$ in 2011; Figure 1 also shows that these flows are relatively more stable than other private and official flows, such as foreign direct investment (FDI), portfolio investment, and official development assistance (ODA) flows. Insofar as Mexico is concerned, it is the largest recipient of remittance flows in Latin America (and the third largest recipient in the world, after India and China) and, not surprisingly, it also recorded a dramatic increase in these flows for the period under review, from a level of US\$10.2 bn in 2001 to US\$26.3 bn in 2008 before falling to an estimated US\$22bn in 2010 - a figure that far surpassed the country's FDI inflows for that year (see ECLAC, 2011; World Bank, 2011). In fact, remittance flows have become such an important source of foreign exchange earnings for the country over the last decade that they rank third, just behind Mexico's earnings from maquiladoras (assembly-line industry) and oil (see Canas et. al., 2007). Given the magnitude of these flows, both in absolute and relative terms, a growing literature has emerged that attempts to assess empirically the economic determinants of these flows to the region and individual countries, as well as their impact on economic growth, investment, savings, and poverty-to name a few. However, there are relatively few extant studies - and none for Mexico-that try to assess over a sufficiently long time span the economic impact of these flows on a country's economic and labor productivity growth rates. In this study we attempt to overcome this lacuna in the extant literature by estimating a modified dynamic production function for Mexico over the 1970-2010 period. The layout of the paper is as follows: First, the paper gives an overview of remittance flows to Mexico during the 1980-2010 period in absolute terms, relative to GDP, and in terms of their regional destination. Second, it reviews the growing literature that attempts to assess empirically the impact of remittances on economic growth for selected developing countries, including several in Latin America and the Caribbean. Third, to motivate the discussion it presents a simple endogenous growth model that explicitly incorporates the potential impact of remittance flows on economic and labor productivity growth. The fourth section presents a modified empirical counterpart to the simple model presented in Section III and, using both single-and two-break unit root tests and cointegration analysis with a level shift, generates error correction models for economic growth and labor productivity growth. The concluding section summarizes the major results and discusses potential avenues for future research on this important topic. 


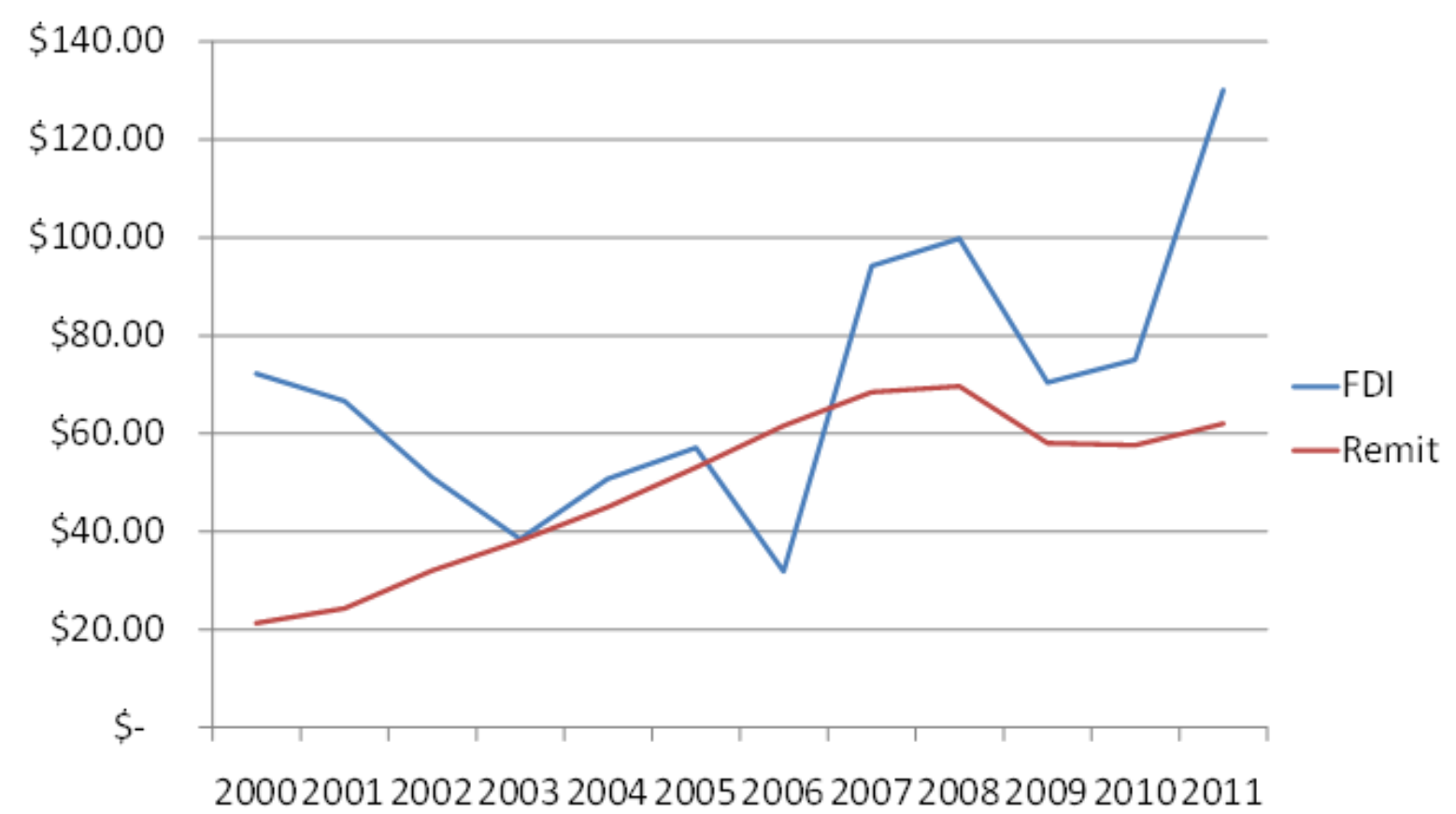

Figure 1. FDI and Remittance Flows to Latin America, 2000-2011 (Billions of dollars).

\section{Overview of Remittance Flows to Mexico}

Although remittance flows to Mexico did not increase dramatically until the decade of the 2000s, they were by no means inconsequential during the decades of the 1980s and 1990s as shown in Table 1 below. Between 1980 and 1989 remittance flows almost tripled from US $\$ 1.04$ bn to US $\$ 2.8$ bn, and then more than doubled between 1990 and 1999, from US\$3.1 to US6.7 bn. Notably, for a number of years during the early 1990s and 2000s, remittance flows rivaled or exceeded Mexico's inflows of FDI. From a relative standpoint, remittances increased as a share of gross domestic product (GDP) from a mere 0.5 percent of GDP in 1980 to a high of 2.3 percent of GDP in 1988, before falling somewhat during the decade of the 1990s to a stable and relatively high annual average of 1.4 percent of GDP. More importantly, perhaps, given remittances' potential role in financing private capital formation, remittance flows as a proportion of Mexico's gross domestic capital formation (GDCF) rose from 4.3 percent in 1980 to 11.7 percent in 1988, and then stabilized at an annual average of about 9 percent of GDCF for the decade of the 1990s. The rapid growth in remittance flows to Mexico during the 1990s can be explained, in part, by the 1994-95 peso crisis which dramatically increased migratory flows to the U.S. in search of employment opportunities; the plentiful job opportunities associated with the rapid economic growth experienced by the U.S. economy during the 1995-1999 period; and the credit-driven boom in U.S. construction activity where a disproportionate number of migrants find employment. 
Table 1. Remittance Flows to Mexico in Absolute and Relative Terms, 1980-2010.

\begin{tabular}{|c|c|c|c|c|}
\hline Year Remit. & (USS, bn) & Remit. (\% GDP) & Remit. ( $\%$ of GDCF) & FDI Inflows (USS, bn) \\
\hline 1980 & 1.04 & 0.54 & 4.3 & 1.62 \\
\hline 1981 & 1.22 & 0.52 & 3.9 & 1.70 \\
\hline 1982 & 1.23 & 1.85 & 16.0 & 0.63 \\
\hline 1983 & 1.39 & 1.25 & 13.4 & 0.68 \\
\hline 1984 & 1.56 & 1.11 & 10.9 & 1.43 \\
\hline 1985 & 1.62 & 1.53 & 19.8 & 1.73 \\
\hline 1986 & 1.77 & 2.04 & 27.1 & 2.42 \\
\hline 1987 & 1.99 & 2.29 & 20.5 & 3.87 \\
\hline 1988 & 2.44 & 1.44 & 11.7 & 3.16 \\
\hline 1989 & 2.79 & 1.49 & 10.7 & 2.50 \\
\hline 1990 & 3.10 & 1.33 & 9.7 & 3.72 \\
\hline 1991 & 3.03 & 1.10 & 7.1 & 3.57 \\
\hline 1992 & 3.70 & 1.13 & 6.8 & 3.60 \\
\hline 1993 & 3.98 & 1.10 & 6.8 & 4.90 \\
\hline 1994 & 4.12 & 1.55 & 10.7 & 10.15 \\
\hline 1995 & 4.37 & 1.82 & 14.2 & 9.53 \\
\hline 1996 & 4.95 & 1.55 & 11.5 & 9.19 \\
\hline 1997 & 5.55 & 1.44 & 6.8 & 12.83 \\
\hline 1998 & 6.50 & 1.70 & 9.2 & 11.31 \\
\hline 1999 & 6.65 & 1.40 & 7.4 & 11.92 \\
\hline 2000 & 7.53 & 1.33 & 7.6 & 13.04 \\
\hline 2001 & 10.15 & 1.70 & 10.4 & 22.37 \\
\hline 2002 & 11.03 & 1.90 & 9.5 & 22.16 \\
\hline 2003 & 16.56 & 2.97 & 15.1 & 15.18 \\
\hline 2004 & 19.90 & 3.24 & 15.8 & 19.22 \\
\hline 2005 & 23.10 & 3.40 & 15.9 & 15.33 \\
\hline 2006 & 26.88 & 3.65 & 16.5 & 13.56 \\
\hline 2007 & 27.14 & 3.44 & 15.2 & 15.22 \\
\hline 2008 & 26.30 & 3.84 & 16.6 & 21.26 \\
\hline 2009 & 21.12 & 3.19 & 14.0 & $8.81 .$. \\
\hline $2010^{\circ}$ & 22.00 & 3.12 & 14.3 & 6.22 .1 \\
\hline
\end{tabular}

Sources: World Bank (2009; 2011); Nacional Financiera, S.A. La Economia Mexicana en Cifras, various issues; and INEGI. aFigures for 2010 are preliminary and subject to revision.

During the decade of the 2000s, up until the year 2007, i.e., before the adverse effects of the Great Recession of 2008-09 began to be felt, Table 1 shows that remittance flows to Mexico increased dramatically, both in absolute terms and relative to GDP and gross domestic capital formation (GDFC). For example, in 2000 remittance flows amounted to US\$7.53 bn and represented 1.3 percent of GDP and 7.6 percent of GDFC; by 2007 they had shot up to US\$27.1 bn, which represented 3.4 percent of GDP and 15.2 percent of GDFC. In fact, Mexico was by far the largest beneficiary of remittance flows in all of Latin America and the Caribbean, and among the relatively larger economies of the region it was, with the exception of Peru, the biggest recipient in relation to its gross domestic product (and GDFC) over the entire 2000-2010 period. The importance of these flows is further revealed by comparing them with FDI inflows to Mexico for the period under review. As can be seen from Table 1, remittance flows began to rival FDI inflows in 2000 and exceeded them by a significant margin after 2004, particularly during the recessionary years of 2009-2010.

From a regional standpoint, Canas et. al. report that the lion's share of remittances were sent to the middle income (and poor) central western-states of Michoacan, Guanajuato, Morelos, 
Zacatecas, and Estado de Mexico (all at least 5\% of gross state product). Several of the poorer southern states (Oaxaca, Guerrero and Chiapas) also received significant amounts of remittance flows (at least 5\% of GSP). Only the wealthier border-states (Sonora, Chihuahua, Coahuila, and Nuevo Leon) received lower remittance flows (below 1\% of GSP) because relatively few low-skilled workers emigrate to the United States from these states. Although the Banco de Mexico supplies information on the regional destination of remittance flows within Mexico, the United States does not systematically track the origins of these flows within the United States. However, the IDB's annual survey of remittance flows to Latin America gives us some indication of where these flows originated from because they ranked, not surprisingly, California first ( $\$ 13.2$ bn), Texas second ( $\$ 5.2$ bn), and New York third ( $\$ 3.7$ bn) (see Canas et. al., p. 4).

With the onset and aftermath of the Great Recession of 2008-09, remittance flows to Latin America in general, and Mexico in particular, have experienced an abrupt decline. For example, according to the World Bank (2011), between 2008 and 2009 Latin America and the Caribbean witnessed a decline in remittance flows of almost 10 percent, from $\$ 65$ bn to $\$ 58$ bn, while Mexico saw its remittance flows drop from $\$ 26.3$ bn to $\$ 21.1$ bn, or a 17.6 percent decline. However, in its 2012 report, the World Bank estimates that, after remaining flat in 2010, remittance flows to Latin America and the Caribbean will rise in 2011, with Mexico registering a slight increase to about US\$22bn in 2010 (see Table 1) and a more substantial rise to US24 bn in 2011. The sharp initial decline in the case of Mexico can be partly explained by the steep drop in construction employment in the U.S. during 2009-10, where there is usually a lag of 4 to 6 months between a drop in economic activity (employment) and remittance flows to Mexico (see Mohapatra et al., 2011).

To make matters worse, the economic recovery in the U.S. has been lackluster and the prediction by many economists is for a "jobless recovery" at least during the coming years. This means that the employment prospects and income levels of existing and prospective migrants will be adversely affected in years to come, thus undermining their willingness to migrate to the U.S. or, if already here, their ability to send remittances back home. Remittance flows to Mexico are also expected to remain weak in the coming years because tighter border controls have led to a significant reduction in emigration flows from Mexico beginning in the second quarter of 2008 and continuing through 2009 (INEGI, 2010).

\section{The Impact of Remittance Flows on Economic Growth and Development}

In general, remittances are expected to have a positive effect on the economic growth of the recipient countries when they complement national savings and augment the total pool of financial resources for investment projects. In this connection, Solimano (2003) and Orozco (2004) report that migrants in the United States, including Ecuadorans, Guatemalans, Mexicans, and Salvadorans, have formed permanent associations known as Home Town Associations (HTAs) which regularly send donations back to their communities to finance investments in small businesses and infrastructure projects such as water treatment plants, roads, bridges, and schools. To the extent that these flows become "institutionalized," their positive effects on growth are likely to become more permanent. ${ }^{\mathrm{i}}$ 


\section{$\triangle$ Macrothink}

Business and Economic Research

ISSN 2162-4860

2014, Vol. 4, No. 1

Similarly, Ratha (2003) found that remittances had a positive and significant effect on investment in receiving countries such as Mexico, Egypt, and Sub-Saharan Africa. In this connection, Aitymbetov (2006) discovered that approximately 10 to 20 percent of remittances were used as some form of investment in Kyrzastan, and thus had a positive impact on the economy. Giuliano et al. (2006) also conclude that remittances help boost the growth rate of the economy in less financially developed countries by providing credit which would otherwise not be available. Insofar as Mexico is concerned, investigators have found that remittances are used to finance investment in micro-enterprises. For example, Woodruff (2006) found that there is, in general, a positive relation between investment spending and the growth of micro-enterprises. Woodruff determined that between 10 to 20 percent of remittance flows are invested in micro-enterprises and that this could have a significant impact on the long-term growth of these labor-intensive enterprises.

Other authors have found a positive and statistically significant relationship between remittance flows and economic growth. For example, Mundaca (2005), in a study assessing the impact of remittances on growth in selected countries in Central America, found a strong correlation between remittances and economic growth. Remittances had a significant impact on the growth of these economies, and the impact was stronger when the financial sector was included in the model. Mundaca carried out several estimations on the impact of remittances on growth using different variables to proxy for financial development. When domestic credit from banks was used as one of the explanatory variables, a 10 percent increase in remittances as a percentage of GDP increased GDP per capita by $3.49 \%$. However, when no variables were included to proxy for financial development, a 10 percent increase in remittances as a percentage of GDP increased GDP per capita at a lower rate of $3.18 \%$. In a more recent study, Sharma and Ramirez (2009), using the Fully-Modified OLS (FMOLS) methodology, report panel estimates for selected upper and lower income Latin American and Caribbean countries which suggest that remittances have a positive and significant effect on economic growth in both groups of countries. In addition, the interaction of remittances with a financial development variable reveal that these two variables act as substitutes and, similar to Mundaca's findings, the impact of remittances is more pronounced in the presence of the financial development variable.

However, the positive effects of remittances on economic growth are not readily accepted by other scholars working on this topic. Chami et al. (2005) report a negative correlation between remittances and growth, while, in a more recent IMF panel study for 84 countries, Barajas et al. (2009) find that workers' remittances have little or no effect on long run economic growth. By and large, remittances were found to be counter-cyclical in nature. For example, Chami et al. argue that remittances act like compensatory transfers and, hence, do not aid in the process of economic growth. They contend that remittances are intended for consumption rather than investment. This finding is also supported by the work of Solimano (2003). He reports that in the case of Ecuador around 60 percent of remittances are spent on food, medicines, house rents, and other basic commodities (p. 16).

Another possible negative effect on growth associated with remittances may result from the possibility of a "Dutch Disease" effect via an induced real appreciation of the domestic 
currency for countries with sizable remittance flows. For example, in a recent study Acosta et al. (2008) report (unbalanced) panel estimates for 109 developing and transition economies over the 1990-2003 period which suggest that rising levels of remittance flows lead to real exchange appreciation and resource movements that favor the non-tradable sector at the expense of the tradable sector. To the degree that this happens, traditional and non-traditional exports (and import-competing industries) may be adversely affected, thus undermining investment spending and growth.

Finally, there are a several economic, institutional and social factors which have a potential effect on the size of remittance flows, and thus economic growth. The size of the migrant population, the length of stay away from their home country, the migrants' income and that of family members back home, volatility of exchange rates, the economic freedom of the source country, the transfer costs, and the migrants' motivation to go back (see Canas et al., 2007).

\section{Conceptual Model}

For reasons outlined above, remittance flows may have either positive or negative effect on the long-term growth prospects of a country. To the degree that they contribute to the financing of private capital formation, they augment both the stock of private capital and the productivity of labor, thus enhancing the country's long-term economic growth. On the other hand, if remittances are primarily channeled to finance current consumption, then they reduce current investment spending, thereby reducing the stock of private capital and the country's long-term growth prospects. Of course, it is possible that remittance flows are used by family members to finance expenditures on education and/or vocational training, and to the extent that they do, then they contribute to the formation of human capital, thus promoting future economic growth. Following the lead of De Mello (1997) and De Vita (2004), remittance flows can be treated as a form of foreign capital that generates positive or negative externality effects to the domestic economy. It can be explicitly modeled via an augmented Cobb-Douglas production function of the following form:

$$
Y=A f\left[L, K_{p}, E\right]=A L^{\alpha} K^{\beta} E^{(1-\alpha-\beta)}
$$

Where $\mathrm{Y}$ is real output, $\mathrm{K}_{\mathrm{p}}$ is the private capital stock, $\mathrm{L}$ is labor, and $\mathrm{E}$ refers to the positive or negative externality generated by additions to the stock of foreign capital in the form of remittance flows. $\alpha$ and $\beta$ are the shares of domestic labor and private capital respectively, and A captures the efficiency of production. It is also assumed that $\alpha$ and $\beta$ are less than one, such that there are diminishing returns to the labor and capital inputs. The externality, E, can be represented by a Cobb -Douglas function of the type:

$$
\mathrm{E}=\left[\mathrm{L}, \mathrm{K}_{\mathrm{p}}, \mathrm{K}_{\mathrm{r}}^{\gamma}\right]^{\theta}
$$

Where $\gamma$ and $\theta$ are, respectively, the marginal and the intertemporal elasticities of substitution between private and foreign capital in the form of remittance flows. Let $\gamma>0$, such that a larger stock of remittances generates a positive externality to the economy; i.e., knowledge or technological progress is an accidental by-product of capital investment by relatively small firms in the form of remittances. If $\theta>0$, intertemporal complementarity prevails and, if $\theta<0$, additions to the stock of foreign capital in the form of remittances crowd out private capital 
over time and diminish the growth potential of the host country.

Combining equations (1) and (2), we obtain,

$$
\mathrm{Y}=\mathrm{AL}^{\alpha+\theta(1-\alpha-\beta)} \mathrm{K}_{\mathrm{p}}^{\beta+\theta(1-\alpha-\beta)} \mathrm{K}_{\mathrm{r}}^{\gamma \theta(1-\alpha-\beta)}
$$

A standard growth accounting equation can be derived by taking logarithms and time derivatives of equation (3) to generate the following dynamic production function:

$$
\mathrm{g}_{\mathrm{y}}=\mathrm{g}_{\mathrm{A}}+[\alpha+\theta(1-\alpha-\beta)] \mathrm{g}_{\mathrm{L}}+[\beta+\theta(1-\alpha-\beta)] \mathrm{g}_{\mathrm{Kp}}+[\gamma \theta(1-\alpha-\beta)] \mathrm{g}_{\mathrm{Kr}}
$$

Where $g_{i}$ is the growth rate of $i=Y, A, L, K_{p}$, and $K_{r}$. Equation (4) states that (provided $\gamma$ and $\theta>0$ ) additions to the stock of foreign capital in the form of remittances will augment the elasticities of output with respect to labor and capital by a factor $\theta(1-\alpha-\beta)$.

\subsection{Empirical Model}

Mexico has a sufficiently long (and official) time series data set (extending back to the decade of the fifties and sixties) for a number of key variables, including private investment spending, public capital formation, and FDI inflows, so that using a perpetual inventory method capital stock data can be generated for the different types of capital. Insofar as remittance flows are concerned, there is annual data going back only to the decade of the seventies, so it is not possible to generate a capital stock measure for this variable. Nevertheless, there are still a sufficient number of data points (41) to test empirically whether these flows have a beneficial or adverse impact on economic growth.

Official data on the economically active population (EAP), rather than just population data per se, are also available for the period under review. This study is thus the first, other than Woodruff's (2006) at the micro level, to test whether remittance flows have a positive or negative effect on economic growth (and labor productivity growth) in Mexico during the 1970-2010 period. The most general formulation of the dynamic production function is given below,

$$
\Delta \mathrm{Y}=\alpha+\beta_{1} \Delta \mathrm{L}+\beta_{2} \Delta \mathrm{K}_{\mathrm{p}}+\beta_{3} \Delta \mathrm{K}_{\mathrm{g}}+\beta_{4} \Delta \mathrm{K}_{\mathrm{f}}+\beta_{5} \Delta \mathrm{R}+\beta_{6} \mathrm{D}_{1}+\beta_{7} \mathrm{D}_{2}+\varepsilon_{\mathrm{t}}
$$

$\Delta$ is the difference operator; Y represents the natural log of real GDP (1970 pesos); L, as indicated above, refers to the natural $\log$ of the EAP; $\mathrm{K}_{\mathrm{p}}$ denotes the natural $\log$ of the stock of private capital (1970 pesos); $\mathrm{K}_{\mathrm{g}}$ denotes the natural $\log$ of the stock of public capital; $\mathrm{K}_{\mathrm{f}}$ denotes the log of the stock of FDI capital (1970 pesos); $\mathrm{R}$ is the natural log of remittance flows (1970 pesos); $D_{1}$ is a dummy variable that equals 1 for the crises years of 1976, 1982-83, 1987, 1995, 2001, and 2009, and 0 otherwise; $\mathrm{D}_{2}$ equals 1 for the petroleum-led expansion of 1978-81, and 0 otherwise; Finally, $\varepsilon_{\mathrm{t}}$ is a normally distributed error term.

The economic rationale for the inclusion of the additional variables in equation (5) and the interpretation of their respective coefficients is given below. The coefficients represent the annual percentage change in real GDP associated with a respective percentage change in the variables in question. Following the lead of Aschauer (1989) and Blomstrom and Wolff (1994) equation (5) was estimated as a labor productivity growth equation by defining the variables in per capita terms using the economically active population. ${ }^{\text {ii }}$ All right-hand side variables have 
been lagged in order to minimize the inherent problem of reverse causality associated with some of the included variables. The sign of $\beta_{1}$ is anticipated to be positive in both the GDP growth rate formulation and labor productivity growth rate specification. $\beta_{2}$ is expected to be positive, while the sign of $\beta_{3}$ can be positive or negative depending on whether government investment spending "crowds in" or "crowds out" private investment spending. To the extent that public investment spending is directed to economic and social infrastructure in the form of roads, bridges ports, and primary education, it is likely to reduce the cost of doing businesses and thereby crowd in private investment spending. On the other hand, if public investment spending is channeled primarily to sectors that directly compete with the private sector and/or indirectly raise the cost of credit by competing for scarce funds, then it is likely to crowd out private investment spending (see Aschauer, 1989; Barro, 1990; and Ramirez, 2007).

Insofar as foreign capital is concerned, FDI inflows are likely to complement private capital formation if they bring needed financing and transfer managerial and technological knowhow (see Huang, 2004). In this connection, the impact of remittance flows will be beneficial to long-term growth if, like FDI inflows, they contribute to financing private capital formation and are directed to investments in human capital and economic infrastructure rather than consumption expenditures per se. In view of these ambiguous effects, the signs of, $\beta_{4}$ and $\beta_{5}$ are indeterminate. $\mathrm{B}_{6}$ is anticipated to have a negative sign for obvious reasons. $\mathrm{B}_{7}$ is expected to be positive because of the high rates of economic growth associated with the short-lived petroleum boom of 1978-81.

The economic data used in this study were obtained from official government sources such as INEGI (various issues), Nacional Financiera, S.A., La Economia Mexicana en Cifras, the Banco de Mexico, Informe Anual (various issues), and the World Bank's Migration and Development Brief (various issues). Private and public investment data for Mexico have been obtained from International Finance Corporation, Trends in Private Investment in Developing Countries: Statistics for 1970-2000 [2002]. ${ }^{\text {iii }}$ The private, public and foreign capital stock data were generated using a standard perpetual inventory model assuming an estimate of the rate of depreciation of 5 percent.

\section{Empirical Results}

Initially, conventional unit root tests (without a structural break) were undertaken for the variables in question given that it is well-known that macro time series data tend to exhibit a deterministic and/or stochastic trend that renders them non-stationary; i.e., the variables in question have means, variances, and covariances that are not time invariant. In their seminal paper, Engle and Granger (1987) showed that the direct application of OLS or GLS to non-stationary data produces regressions that are misspecified or spurious in nature. Consequently, this study tested the variables in question for a unit root (non-stationarity) by using an Augmented Dickey-Fuller test (ADF) (Dickey-Fuller, 1981) with a constant and deterministic trend.

It is important to acknowledge that when dealing with historical time series data for developing countries such as Mexico or Chile investigators are often constrained by the relatively small number of time series observations (usually in annual terms). This is the case in this study 
where the sample size is below the threshold level of 50 observations recommended by Granger and Newbold (1986), and thus may compromise the power of the unit root (and cointegration) tests-not to mention distort the size or significance of the tests as well [see Charemza and Deadman, 1997]. However, a growing literature contends that the power of unit root (and cointegration) tests depends on the length or time span of the data more than the mere number of observations in the sample. That is, for a given sample size $\mathrm{n}$, the power of the test is greater when the time span is large. Thus, unit root or cointegration tests based on 40 observations over 40 years have considerable more power than those based on 100 observations over 100 days (see Bahnam-Oskooee 1996; Hakkio and Rush, 1991). ${ }^{\text {iv }}$

Following the Doldado et al. (1990) procedure, Table 2 (part A) below presents the results of running an Augmented Dickey-Fuller test (one lag) on the variables in logarithmic form with a constant and a deterministic trend. ${ }^{\mathrm{v}}$ The results indicate that the null hypothesis of non-stationarity cannot be rejected for any of the variables in level form with a deterministic trend, suggesting that the variables in question do not exhibit a deterministic time trend throughout the period under review. In other words, the common practice of detrending the data by a single trend line will not render the data in question stationary because the trend line itself may be shifting over time (see Charemza and Deadman, 1997). ${ }^{\text {vi }}$ When the ADF test is applied to these variables in first differences under the assumption of a constant and deterministic time trend, all of the variables become stationary at the five percent level of significance.

In view of the relatively low power of the ADF unit root tests when the data generating process is stationary but with a root close to the unit root, Table 2 (part B) presents the results of running a KPSS stationarity test ( Kwaitkowski et al., 1992). This test has a no unit root (stationary) null hypothesis, thus reversing the null and alternative hypotheses under the Dickey Fuller test. It is used as a confirmatory test because in the presence of insufficient information, due to a relatively small sample size, it defaults to the stationary data generating process. The reported results in both level and differenced form under the assumption of a deterministic trend are consistent with those reported in Table 2 (part A). For example, the null hypothesis of no unit root can be rejected for all the variables in level form at the 5 percent level of significance; i.e., they appear to follow a random walk with (positive) drift. In the case of first differences, however, the null hypothesis of stationarity cannot be rejected for all variables at least at the 5 percent level. Thus, the evidence presented suggests that the variables in question follow primarily a stochastic trend as opposed to a deterministic one, although the possibility that for given subperiods they follow a mixed process cannot be rejected.

\subsection{Single-Break Unit Root Analysis.}

Although suggestive, the results reported in Table 2 may still be misleading because the power of conventional unit root tests may be significantly reduced when the stationary 


\section{$\triangle$ Macrothink}

Business and Economic Research ISSN 2162-4860 2014, Vol. 4, No. 1

Table 2. Part A. ADF Unit Root Tests for Stationarity with constant and time trend, sample Period 1970-2010.

\begin{tabular}{|c|c|c|c|}
\hline Variables & Level & First Difference & $5 \%$ Critical Value \\
\hline $\mathrm{Y}$ & -1.74 & $-6.74^{*}$ & -3.53 \\
\hline $\mathrm{L}$ & 0.41 & $-6.31^{*}$ & -3.53 \\
\hline $\mathrm{K}_{\mathrm{p}}$ & -2.46 & $-4.21^{*}$ & -3.53 \\
\hline $\mathrm{K}_{\mathrm{f}}$ & -2.41 & $-3.62^{*}$ & -3.53 \\
\hline $\mathrm{K}_{\mathrm{g}}$ & -2.18 & $-6.76^{*}$ & -3.53 \\
\hline $\mathrm{R}$ & -1.95 & $-7.60^{*}$ & -3.53 \\
\hline
\end{tabular}

MacKinnon (1966) critical values for rejection of hypothesis of a unit root. * denote significance at the 5 percent level.

Part B. KPSS (LM) No Unit Root Tests for Stationarity with constant and time trend, Sample Period 1970-2010.

\begin{tabular}{|c|c|c|c|}
\hline Variables & Levels & First Difference & 5\% Critical Value \\
\hline $\mathrm{Y}$ & $0.24^{*}$ & 0.05 & 0.14 \\
\hline $\mathrm{L}$ & $0.20^{*}$ & 0.10 & 0.14 \\
\hline $\mathrm{Kp}$ & $0.17^{*}$ & 0.09 & 0.14 \\
\hline $\mathrm{Kf}$ & $0.15^{*}$ & 0.12 & 0.14 \\
\hline $\mathrm{Kg}$ & $0.24^{*}$ & 0.11 & 0.14 \\
\hline $\mathrm{R}$ & $0.18^{*}$ & 0.10 & 0.14 \\
\hline
\end{tabular}

Asymptotic critical values for rejection of null hypothesis of no unit root (LM-Stat.).*denotes significance at 5 percent level.

alternative is true and a structural break is ignored (see Altinay, 2005; and Perron, 1989); that is, the investigator may erroneously conclude that there is a unit root in the relevant series. In order to test for an unknown one-time break in the data, Zivot and Andrews (1992) developed a data dependent algorithm that regards each data point as a potential break-date and runs a regression for every possible break-date sequentially. The break date is selected where the t-statistic from the ADF test of unit root is at its most negative; i.e., a break date will be chosen where the evidence is least favorable for the null hypothesis of a unit root. The test involves running the following three regressions (models): model A which allows for a one-time change in the intercept of the series; model B which permits a one-time change in the slope of the trend function; and model $\mathrm{C}$ which combines a one-time structural break in the intercept and trend (Waheed et. al., 2006).

Following the lead of Perron, most investigators report estimates for either models $\mathrm{A}$ and $\mathrm{C}$, but in a relatively recent study Seton (2003) has shown that the loss in test power (1- $\beta$ ) is considerable when the correct model is $\mathrm{C}$ and researchers erroneously assume that the break-point occurs according to model A. On the other hand, the loss of power is minimal if the break date is correctly characterized by model A but investigators erroneously use model $\mathrm{C}$. Table 3 reports the Zivot-Andrews (Z-A) one-break unit root test results for model $\mathrm{C}$ in level form along with the endogenously determined one-time break date for each time series. With 


\section{Macrothink}

Business and Economic Research

ISSN 2162-4860

2014, Vol. 4, No. 1

the notable exception of the remittances variable, the unit root null hypothesis with a structural break in both the intercept and the trend cannot be rejected at the 5 percent level of significance. ${ }^{\mathrm{vii}}$ The Z-A test identifies endogenously the single most significant structural break in every time series. The exception for the remittances variable is either due to the presence of more than one structural break or the abrupt break in 1970 due to the lack of reported data before that year. In view of space constraints, Figure 2 below shows visually the endogenously determined break-date for the real GDP series.

Table 3. Zivot-Andrews One-break Unit Root Test, Sample Period 1960-2010.

\begin{tabular}{|c|c|c|c|}
\hline Variables & Levels & Break Year & 5\% Critical Value \\
\hline $\mathrm{Y}$ & -5.00 & 1978 & -5.08 \\
\hline $\mathrm{L}$ & -2.29 & 1992 & -5.08 \\
\hline $\mathrm{Kp}$ & -4.32 & 1985 & -5.08 \\
\hline $\mathrm{Kf}$ & -4.46 & 1984 & -5.08 \\
\hline $\mathrm{Kg}$ & -4.80 & 1978 & -5.08 \\
\hline $\mathrm{R}$ & $-6.23 *$ & 1970 & -5.08 \\
\hline
\end{tabular}

Values for rejection of null hypothesis of a unit root with a structural break in both the intercept and trend (Model C). *Denotes significance at the 5 percent level.

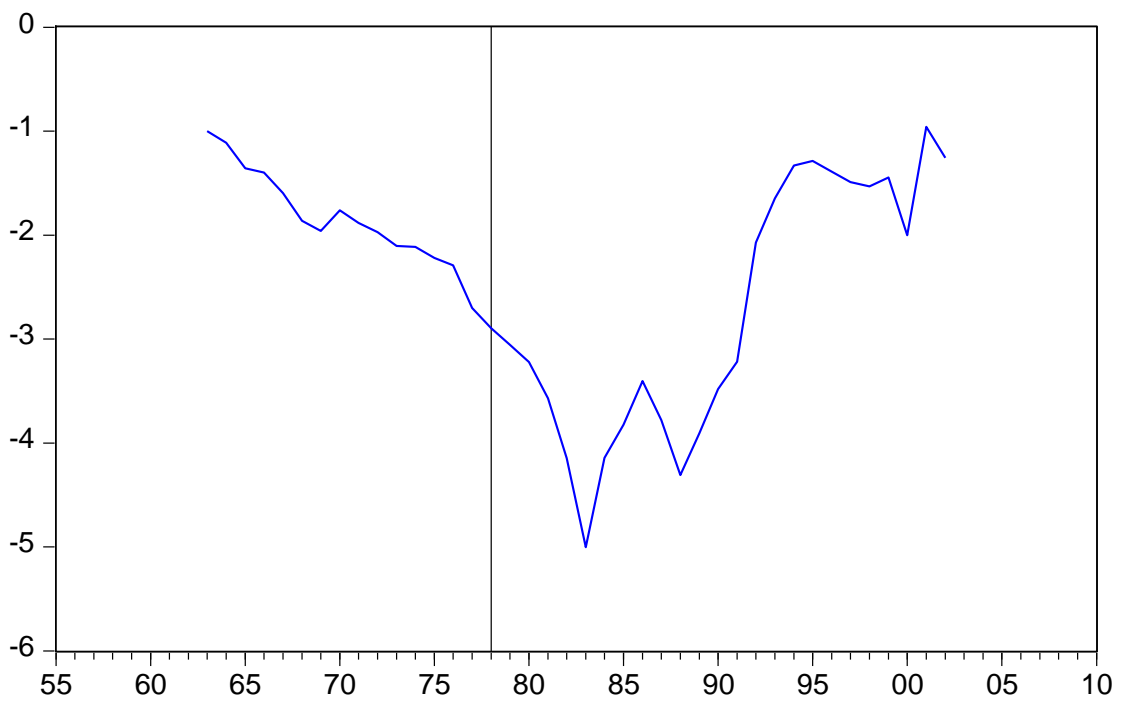

Fig. 2 Zivot-Andrew Breakpoints

\subsection{Two-Break Unit Root Analysis}

The analysis undertaken so far only tests for the presence of a single endogenously determined structural break. However, Lee and Strazicich (2003) have developed a two-break minimum Lagrange Multiplier (LM) unit root test that shows that assuming erroneously that there is one structural break in the data when, in fact, there are two leads to a further loss of power. Moreover, the LM unit root test developed by Lee and Strazicich enables the investigator to properly test for structural breaks under both the null and alternative hypotheses, thus eliminating size distortions that lead to the over-rejection of the null hypothesis of a unit root 
(see Altinay, 2005). This study therefore performed two-break unit root tests for all the variables in level form utilizing the @LSUNIT (model=crash, breaks=2) program in Rats 7.3, and determined that the null hypothesis of a unit root under two endogenously determined structural (intercept) breaks could not be rejected at either the 1 or 5 percent level of significance. Thus, the more powerful Lee-Strazicich unit root test strongly suggests that all the included variables are I(1), which is contrary to the results obtained for the remittances variable using the Zivot-Andrews procedure unit root results for the log of real GDP (Y), the log of remittances (R), and the log of the stock of private capital $(\mathrm{Kp})$ are reported in Table 4 below.

Table 4. Lee- Strazicich Two-Break Unit Root Test, 1970-2010.

\begin{tabular}{|l|l|l|l|l|}
\hline Variable & Coefficients & T-ratios & $1 \% \mathrm{cv}$ & $5 \% \mathrm{cv}$ \\
\hline SY(-1) & -0.305 & -2.55 & -4.545 & -3.842 \\
\hline Constant & 0.070 & 4.39 & --- & --- \\
\hline B1: 1977 & 0.141 & 2.82 & --- & --- \\
\hline B2: 1981 & 0.010 & 0.18 & --- & --- \\
\hline SR(-1) & -0.334 & -2.69 & -4.545 & -3.842 \\
\hline Constant & 0.205 & 3.81 & --- & --- \\
\hline B1: 1976 & -0.033 & -0.11 & --- & --- \\
\hline B2: 2006 & 0.005 & 0.01 & --- & --- \\
\hline SKp (-1) & -0.10 & -1.31 & -4.545 & -3.842 \\
\hline Constant & 0.07 & 9.69 & --- & --- \\
\hline B1: 1981 & 0.02 & 0.57 & --- & --- \\
\hline B2: 1985 & -0.05 & -2.60 & --- & --- \\
\hline
\end{tabular}

Notes: The coefficients on the SY(-1), SR(-1), and SKp(-1) lagged de-trended variables tests for the presence of a unit root; B1 and B2 equal the endogenously determined breaks in the intercept for the sample period. Estimations undertaken with Rats7.3.

\subsection{Cointegration Analysis with Structural Breaks.}

To determine whether there exists a stable and non-spurious (cointegrated) relationship among the regressors, this study employed the cointegration method first proposed by Johansen (1988). The Johansen method was chosen over the one originally proposed by Engle and Granger (1987) because it is capable of determining the number of cointegrating vectors for any given number of non-stationary series (of the same order), its application is appropriate in the presence of more than two variables, and more important, Johansen (1988) has shown that the likelihood ratio tests used in this procedure (unlike the DF and ADF tests) have well-defined limiting distributions.

To save space, Table 5 below reports the Johansen maximum L.R. test for cointegration for only the output equation. ${ }^{\text {vii }}$ The first column of the table gives the eigenvalues in descending order, while the second column reports the corresponding trace statistics generated from the maximum L.R. test statistic. The next two columns report, respectively, the 5 percent critical and p-values. Finally, the last column gives the null hypotheses, ranging from no cointegrating 
relationships up to at most four cointegrating vectors. It can be ascertained from the L.R. ratio statistics that, in the presence of a constant in the cointegrating and VAR equation, there exists a linear combination of the $\mathrm{I}(1)$ variables that links them in a stable and long-run relationship. In fact, the p-value reported in the table shows that the null

Table 5. Johansen Cointegration (Trace) Test, 1970-2010.

Series: $\mathrm{Y}, \mathrm{L}, \mathrm{K}_{\mathrm{p}}, \mathrm{K}_{\mathrm{f}}$, and $\mathrm{R}$.

Test assumptions: Intercept (no trend) in CE and VAR; $\mathrm{K}_{\mathrm{g}}, \mathrm{D}_{1}$, and $\mathrm{D}_{2}$ are treated as exogenous variables.

\begin{tabular}{lrrrc}
\hline Eigenvalue & Likelihood Ratio & \multicolumn{1}{l}{$5 \%$} & P-value & No. of CE(s) \\
\hline 0.957 & 170.027 & 69.82 & 0.000 & None \\
0.452 & 46.866 & 47.856 & 0.062 & At most 1 \\
0.307 & 23.392 & 29.797 & 0.227 & At most 2 \\
0.204 & 9.093 & 15.495 & 0.357 & At most 3 \\
0.005 & 0.203 & 3.842 & 0.653 & At most 4 \\
\hline
\end{tabular}

B. Normalized Cointegrating Vector; coefficients normalized on Y.

\begin{tabular}{lcccccl}
\hline Vector & $\mathrm{Y}$ & $\mathrm{L}$ & $\mathrm{K}_{\mathrm{p}}$ & $\mathrm{K}_{\mathrm{f}}$ & $\mathrm{R}$ & Constant \\
1. & 1.000 & -0.108 & -0.129 & 0.29 & -0.137 & -3.154 \\
& & $(9.87)$ & $(3.22)$ & $(11.6)$ & $(21.1)$ & $(-7.03)$ \\
\hline
\end{tabular}

Note: t-ratios are in parenthesis. Signs are reversed in the cointegrating vector because of the normalization process.

Hypothesis of no cointegrating vector can be rejected at least at the one percent level, thereby suggesting the presence of one cointegrating equation from which residuals (EC terms) can be obtained to measure the respective deviations between the current level of output and the level based on the long-run relationship. The long-run estimates reported in Part B of the Table suggest that all variables, with the notable exception of the foreign capital variable, have positive and highly significant effect on the level of real GDP. ${ }^{\text {ix }}$ Similar results were obtained for the labor productivity function and they are available upon request.

Before turning to the EC models, it should be noted that the cointegrating test performed in this study does not allow for structural breaks in the sample period, whether level (intercept) shifts or regime (intercept and slope) shifts. However, Gregory and Hansen (1996) have shown that ignoring these breaks reduces the power of conventional cointegration tests similar to conventional unit root tests and, if anything, should lead to a failure to reject the null hypothesis of no cointegrating vector, which is clearly not the case in the present study. Still, this study undertook a G-H cointegration test with level shift and the results, which are consistent with the Johansen test, are reported in endnote $10 .^{\mathrm{x}}$ 


\subsection{Error Correction Models.}

The information provided by the L.R. tests is used to generate a set of EC models that capture the short- and long-run behavior of the labor productivity relationship. EC models enable the researcher to estimate the speed of adjustment back to the long-run (stable) condition among the variables. Engle and Granger (1987) warn that failure to include the lagged residual of the cointegrating equation in a (short-run) model in difference form results in a misspecified relationship because the long-run properties of the model are ignored. The changes in the relevant variables represent short-run elasticities, while the coefficient on the EC term represents the speed of adjustment back to the long-run relationship among the variables. For simplicity, consider the EC model with lags (and no dummy variables) given in equation (11) below:

$$
\Delta \mathrm{Y}_{\mathrm{t}}=\alpha+\beta_{1} \Delta \mathrm{L}_{\mathrm{t}-\mathrm{i}}+\beta_{2} \Delta \mathrm{K}_{\mathrm{pt}-\mathrm{I}}+\beta_{3} \Delta \mathrm{K}_{\mathrm{gt}-\mathrm{i}}+\beta_{4} \Delta \mathrm{K}_{\mathrm{ft}-\mathrm{i}}+\beta_{5} \Delta \mathrm{R}_{\mathrm{t}-\mathrm{i}}+\delta \mathrm{EC}_{\mathrm{t}-1}+\varepsilon_{\mathrm{t}}
$$

The coefficients $(\beta=\mathrm{s})$ of the changes in the relevant variables represent short-run elasticities, while the coefficient, $\delta(<0)$, on the lagged EC term obtained from the cointegrating equation in level form denotes the speed of adjustment back to the long-run relationship among the variables. To conserve space, two of the estimated EC models are given below, the growth rate in real GDP and the growth rate in labor productivity (lower case letters denote per capita terms).

$$
\begin{aligned}
& \Delta(\mathrm{Y})_{\mathrm{t}}=-0.06+0.2 \Delta \mathrm{L}_{\mathrm{t}-1}+0.56 \Delta \mathrm{K}_{\mathrm{pt}-2}+0.06 \Delta \mathrm{K}_{\mathrm{gt}-1}+0.06 \Delta \mathrm{K}_{\mathrm{f} t-3}+0.04 \Delta \mathrm{R}_{\mathrm{t}-1}-0.41 \mathrm{EC}_{\mathrm{t}-1}-0.06 \mathrm{D}_{1}+0.07 \mathrm{D}_{2}
\end{aligned}
$$

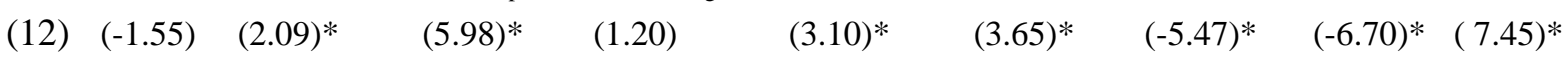

Adj. $\mathrm{R}^{2}=.83$, S.E. $=0.02 \quad$ F-Stat. $=15.65^{*}, \quad$ D.W. $=2.06, \quad$ Akaike criterion $=-4.28$

Schwarz criterion $=-3.76$; Ramsey $($ RESET $)$ test $=3.26(p$-value $=0.083) ; *=5 \%$ significance .

$$
\begin{aligned}
& \Delta(\mathrm{y})_{\mathrm{t}}=-0.02+0.72 \Delta\left(\mathrm{k}_{\mathrm{p}}\right)_{\mathrm{t}-1}+0.11\left(\Delta \mathrm{k}_{\mathrm{g}}\right) \mathrm{t}_{-3}+0.08 \Delta\left(\mathrm{k}_{\mathrm{f}}\right)_{\mathrm{t}-3}+0.05 \Delta(\mathrm{r})_{\mathrm{t}-1}-0.42 \cdot \mathrm{EC}_{\mathrm{t}-1}-0.07 \mathrm{D}_{1}+0.06 \mathrm{D}_{2} \\
& \text { (13) }(-1.52) \quad(7.78)^{*} \quad(1.83)^{*} \quad(3.62)^{*} \quad(3.09)^{*} \quad(-7.58)^{*} \quad(-4.09)^{*}(8.44)^{*}
\end{aligned}
$$

Adj. $\mathrm{R}^{2}=.80, \quad$ S.E. $=0.02, \quad$ F-Stat. $=13.8^{*}, \quad$ D.W. $=2.12$, Akaike criterion $=-4.14$, Schwarz criterion $=-3.66$; Ramset $($ RESET $)$ test $=2.609(\mathrm{p}$-value $=0.117)$.

Where $\Delta(\mathrm{Y})$ and $\Delta(\mathrm{y})$ denote, respectively, real gdp growth and labor productivity growth, and $\mathrm{EC}_{\mathrm{t}-1}$ represents the lagged residual from the cointegrating equation. Both equations were tested for serial correlation via the Breusch-Godfrey LM test and were found to exhibit first order correlation at the 5 percent level of significance. The reported estimates have been corrected for first order serial correlation. In addition, the regressions were tested for specification error such as omitted variables and/or functional form via Ramsey's Regressions Specification Error Test (RESET), and we were unable to reject the null hypothesis of no specification error at the 5 percent level of significance. Finally, the lag structure for the explanatory variables in each equation was chosen on the basis of the AIC (and Schwarz) criteria.

The estimates in equations (12) and (13) suggest that the impact of lagged changes in the growth rate of the private capital stock are positive and statistically (and economically) significant at the 5 percent level, while contemporaneous changes in employment growth have 
a positive impact on the growth rate in real GDP in equation (12). The short-run growth rate in the foreign capital variable (FDI inflows), as opposed to its long-run impact reported in Table 4, has a positive and statistically significant effect when lagged three periods in both equations. The EC estimates for the foreign capital variable are not altogether surprising because the positive externalities generated in the form of a greater transfer of technology and managerial know-how are likely to impact economic growth (and labor productivity) with a lag. The public investment variable has a lagged positive and significant effect (at the 5 percent level) for the labor productivity growth specification, but not for the real GDP growth regression. The relatively weak positive effect may be due to the fact that the variable does not measure economic infrastructure spending per se, but overall public investment spending which includes spending by state-owned enterprises and other public entities. During the 1970s and early 1980s most of the increase in public investment spending was associated with the growth of state-owned enterprises in sectors that were in direct competition with the private sector (see Ramirez, 1989). Insofar as the impact of remittance flows are concerned, the estimates for both equations suggest that they have a positive and highly significant effect when lagged one period, although the economic magnitude of the coefficient is far below that of private capital formation or the foreign capital variable. Moreover, it should be noted that the estimates for the remittance variable are sensitive to the lag structure chosen.

Turning to the dummy variables, the estimates suggest that they have the anticipated signs and are highly significant in both EC regressions. The relative fit and efficiency of both EC regressions is quite good and, as the theory predicts, the EC terms are negative and statistically significant, suggesting, as in equation (13), that a deviation from long-run labor productivity growth this period is corrected by about 65 percent in the next year. Finally, stability tests were undertaken to determine whether the null hypothesis of no structural break could be rejected at the 5 percent level. The Chow breakpoint tests suggested that the hypothesis could not be rejected for the economic crises year $1976(p$-value= 0.453), $1982(p$-value= 0.325), and $1995(\mathrm{p}$-value $=.773)$.

EC models were also used to track the historical data on the percentage growth rate labor productivity during the period under review. Figure 3 below, corresponding to equation (13) above, shows that the model was able to track the turning points in the actual series quite well. PGR refers to the actual series and (PGRF) denotes the in-sample forecast. In addition, Figure 3 shows that the Theil inequality coefficient for this model is 0.216 , which is well below the threshold value of 0.3 , and suggests that the predictive power of the model is quite good [see Theil, 1966]. The Theil coefficients can be decomposed into three major components: the bias, variance, and covariance terms. Ideally, the bias and variance components should equal zero, while the covariance proportion should equal one. The estimates reported in 


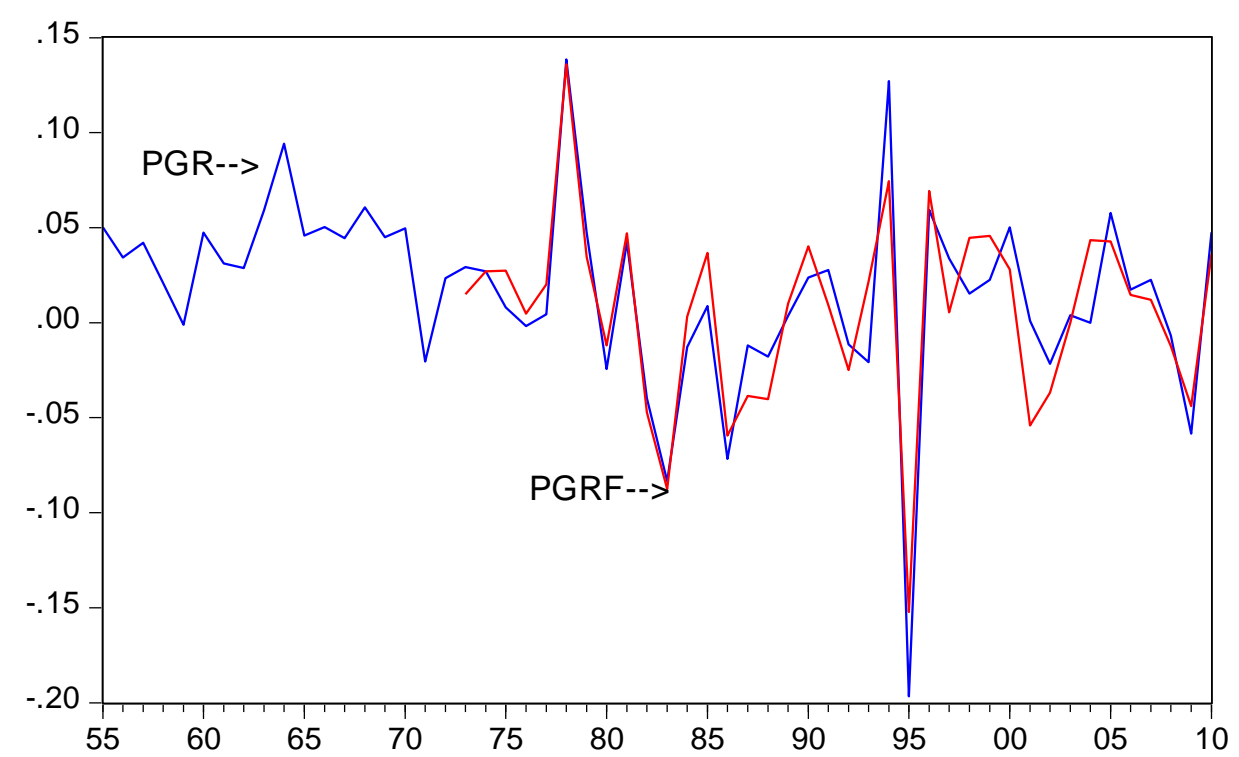

Fig. 3 Actual (PGR) and Simulated (PGRF) Labor Productivity Growth Rates

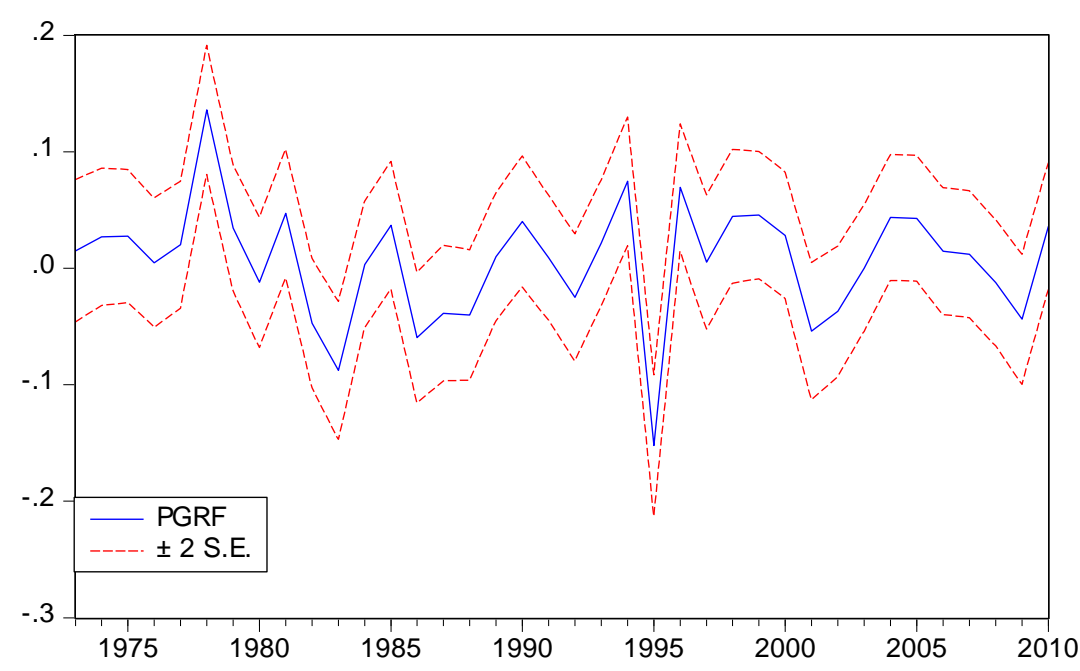

\begin{tabular}{|c|c|}
\hline \multicolumn{2}{|l|}{ Forecast: PGRF } \\
\hline \multicolumn{2}{|l|}{ Actual: PGR } \\
\hline \multicolumn{2}{|l|}{ Forecast sample: 19552010} \\
\hline \multicolumn{2}{|l|}{ Adjusted sample: 19732010} \\
\hline \multicolumn{2}{|l|}{ Included observations: 38} \\
\hline Root Mean Squared Error & 0.022785 \\
\hline Mean Absolute Error & 0.018150 \\
\hline Mean Abs. Percent Error & 191430.6 \\
\hline Theil Inequality Coefficient & 0.216961 \\
\hline Bias Proportion & 0.000000 \\
\hline Variance Proportion & 0.047952 \\
\hline Covariance Proportion & 0.952048 \\
\hline
\end{tabular}

Fig. 4 Theil Inequality Coefficient

Figure 4 suggests that all of these ratios are close to their optimum values (bias $=0.00$, variance $=0.047$, and covariance $=0.952$ ). Sensitivity analysis on the coefficients also revealed that changes in the initial or ending period did not alter the predictive power of the selected models (results are available upon request).

\section{Conclusion}

Remittance flows to Mexico have been substantial since the second half of the eighties and during the decade of the nineties and beyond, particularly in relation to GDP, gross fixed domestic capital formation, and from a regional standpoint. Moreover, these flows have, since the decade of the 2000s, rivaled or even exceeded the country's FDI inflows. Remittance flows also exhibit a greater degree of stability and less susceptibility to the business cycle than FDI inflows which are often referred to as the "good cholesterol" of global (private) financial flows. 


\section{MlMacrothink}

Business and Economic Research

ISSN 2162-4860

2014, Vol. 4, No. 1

This study undertook unit root tests in the presence of both one- and two-time structural breaks. The Lee-Strazicich two-break minimum LM unit root tests are consistent with those obtained from the conventional ADF and KPSS tests but not the Zivot-Andrews single break unit root test. The reported estimates for the Zivot-Andrews test suggest that the null hypothesis of non-stationarity cannot be rejected for the relevant series in level form, with the notable exception of the remittances variable. On the other hand, the more powerful two-break LM unit root test suggests that all variables (including the remittances variable) are non-stationary in level form. This is an important finding because conventional unit root tests such as the ADF test tend to exhibit low power when structural breaks are ignored and the stationary alternative is true; i.e., researchers are more likely to incorrectly conclude that the variable in question has a unit root.

The Johansen cointegration test indicated that there is a unique and stable relationship among the relevant variables in level form which keeps them in proportion to one another over the long run. Moreover, the Gregory and Hansen cointegration test with an endogenous structural (intercept) break also indicates that the null of no cointegration can be convincingly rejected at the one percent level. This is also an important contribution to the extant literature because previous econometric studies relating to the impact of remittances in the Mexican case have failed to determine whether the estimated (cointegrated) relationships were spurious or not in the presence of structural break.

The reported EC models suggest that short-run deviations from long-run labor productivity growth are corrected in subsequent periods and the in-sample forecasts of the EC models are able to track the turning points in the data relatively well. The short-run estimates suggest that remittance flows have a positive, albeit small lagged effect on both the growth rate in real GDP and labor productivity growth over the period in question. The other included quantitative variables also have their anticipated signs and they are, for the most part, statistically and economically significant. Finally, the qualitative variables also have their expected signs and they are statistically significant.

Although suggestive, the positive estimates reported in this study for the remittance variable are by no means conclusive and need to be supported by micro-based case studies and/or sectorial (regional) studies. As more disaggregated data becomes available on a regional or sectorial basis, it will be possible to conduct panel studies to determine whether remittance flows have greater positive (or negative) effects on investment spending and labor productivity growth in certain regions or sectors of the Mexican economy. This should help policymakers and the home town associations alluded to earlier to funnel remittances to where they can have their maximum effect in terms of financing investment, promoting economic growth, and alleviating poverty.

\section{References}

Acosta, Pablo A. et al. (2008). Remittances and the Dutch Disease. Federal Reserve Bank of Atlanta, Working Paper2007-8a (August), 1-22.

Aitymbetov, S. (2006). Emigrant remittances: Impact on economic development of 
Kyrgyzstan.” ICEG Working Paper (June), 1-20.

Altinay, G. (2005). Structural Breaks in Long-Term Turkish Macroeconomic Data, 1923-2003, Applied Econometrics and International Development, 5(4), 117-130.

Aschauer, D. A. (1989). Public Investment and Productivity Growth in the Group of Seven, Economic Perspectives, 13, Sept./Oct.: 17-25.

Bahamani-Oskoee, M. (1996). Decline of the Iranian Rial during the post-revolutionary period: A Productivity Approach, Journal of Developing Areas, 30, 479-92.

Barajas, Adolfo et al. (2009). Do Workers Remittances Promote Economic Growth? IMF Working Paper, No. 153 (July): 1-22.

Barro, R. J. (1990). Government Spending in a Simple Model of Endogenous Growth, Journal of Political Economy, 98(5), 103-125. http://dx.doi.org/10.1086/261726

Bloomstrom, M., and E. Wolff. Multinational Corporations and Productivity Convergence in Mexico. (1994). In Convergence of Productivity: Cross-National Studies Historical Evidence, edited by W. Baumol, R. Nelson, and E. Wolff. Oxford: Oxford University Press.

Canas, J., Coronado, R., \& Orrenius, P. (2007). Explaining the increase in remittances to Mexico. The Southwest Economy, Federal Reserve Bank of Dallas, July/August.

Chami, R., Fullenkamp, C., \& Jahjah, S. (2005). Are immigrant remittance flows a source of capital for development? IMF Staff Papers, 53(1). 57-70.

Charemza, W.W. and D.F. Deadman. (1997). New Directions in Econmetric Practice: General to Specific Modelling, Cointegration and Vector Autoregression. Cheltenham: Edward Elgar Publishers.

De Mello, Jr. Luiz R. (1997). Foreign Direct Investment in Developing Countries and Growth: A Selective Survey. Journal of Development Studies, 34, 1 (October), 1-34. http://dx.doi.org/10.1080/00220389708422501

De Vita, G., \& K. Lawler. (2004). Foreign Direct Investment and its Determinants: A Look to the Past, A View to the Future. In Foreign Investment in Developing Nations, edited by H.S. Kehal. New York: Palgrave Macmillan, Ltd.

Dickey, D., \& W. Fuller, (1979). Likelihood Ratio Statistics for Autoregressive Time Series with a Unit Root. Econometrica, 49 (June): 1057-1072.

Doldado, J., T. Jenkinson, \& S. Sosvilla-Rivero, (1990). Cointegration and Unit Roots, Journal of Economic Surveys, 4, 249-73. http://dx.doi.org/10.1111/j.1467-6419.1990.tb00088.x

ECLAC. (2006-11. Foreign Investment in Latin America and the Caribbean, Various Reports.

Ellerman, D. (2003). Policy Research on Migration and Development, World Bank Policy Research Working Paper, No. 3117. Washington, D.C.: The World Bank.

Engle, R. F., \& C. W. J. Granger. (1987). Cointegration and Error Correction: Representation, 
Estimation, and Testing. Econometrica $55 \quad$ (March): 251-76. http://dx.doi.org/10.2307/1913236

Guiliano, P., \& Ruiz-Arranz, M. (2006). Remittances, Financial Development, and Growth. IMF Working Papers, No. 05-234.

Gregory, A. W., \& B. E. Hansen. (1996). Tests for Cointegration in Models with Regime and Trend shifts." Journal of Econometrics, $70(1), \quad 99-126$. http://dx.doi.org/10.1016/0304-4076(69)41685-7

Hakkio, C. S., \& M. Rush. (1991). Cointegration: How Short is the Long- run? Journal of International Money and Finance, 10, 571-81. http://dx.doi.org/10.1016/0261-5606(91)90008-8

Huang, T. Jr. (2004). Spillovers from FDI in China. Contemporary Economic Policy, 22, 13-25. http://dx.doi.org/10.1093/cep/byh002

Johansen, Soren and K. Juselius. (1990). Maximum Likelihood Estimation and Inference on Cointegration with Applications to the Demand for Money. Oxford Bulletin ofEconomics and Statistics, 52(May): 169-210.

Kwaitkowski, D., Phillips, P.C.B., Schmidt, P., and Shin, Y., (1992). Testing the Null Hypothesis of Stationarity against the Alternative of a Unit Root, Journal of Econometrics, 54: 159-78. http://dx.doi.org/10.1016/0304-4076(92)90104-Y

Lee, J. and M.C. Strazicich. (2003). Minimum Lagrange Multiplier Unit Root Test with Two Structural Breaks, The Review of Economics and Statistics, 85(4), 1082-1089. http://dx.doi.org/10.1162/003465303772815961

Mohapatra, D., D. Ratha, \& A. Silwal. (2011). Outlook for Remittance Flows 2011-13, Migration and Development Brief, No. 16. Washington, D.C.: The World Bank, May.

Mundaca, G. (2005). Can remittances enhance economic growth? the role of financial market development SSRN. Retrieved from http://ssrn.com/paper=799484

Nacional Financiera, S.A. La Economia Mexicana en Cifras. Mexico, D.F.: Nafinsa, various issues.

Perron, P. (1989). The Great Crash, the Oil Price Shock and the Unit Root Hypothesis, Econometrica, 57, 1361-1401. http://dx.doi.org/10.2307/1913712

Ramanarayanan, A. (2009). Ties that Bind: Bilateral Trade's Role in Synchronizing Business Cycles. Economic Letter, 4, 1, January, pp. 1-8. Federal Reserve Bank of Dallas.

Ramirez, M. D. (1997). The Latest IMF-Sponsored Stabilization Program: Does It Represent a Long-term Solution for Mexico's Economy? Journal of Interamerican Studies and Affairs, 39(4), 129-156.

Ramirez, M. D. (2007). A Panel Unit Root and Panel Cointegration Test of the Complementarity Hypothesis in the Mexican Case: 1960-2001. Atlantic Economic Journal, 35, 
343-356. http://dx.doi.org/10.1007/s11293-007-9078-6

Ratha, D. (2003). Workers' Remittances: An important and Stable Source of External Development Finance. Global Development Finance. Washington, D.C.: The World Bank.

Seton , A. (2003). On Unit Root Tests when the Alternative is a Trend Break Stationary Process, Journal Of Business and Economic Statistics, 21, 174-184. http://dx.doi.org/10.1198/073500102288618874

Sharma, H., \& M. D. Ramirez. (2009). Remittances and Growth in Latin America: A Panel Unit Root and Panel Cointegration Analysis, Estudios Economicos de Desarrollo Internacional, 9(1), 5-32.

Solimano, A. (2003). Remittances by Emigrants: Issues and Evidence. Macroeconomias del Desarrollo, 26, Economic Development Division. Santiago: Chile, October.

Theil, H. (1966). Applied Economic Forecasting. Amsterdam: North-Holland.

The World Bank. (2009-11). Migration and Development Brief. Washington, D.C.: Migration and Remittances Unit.

United Nations. (2007). World Investment Report 2007: Trends and Determinants. Switzerland: United Nations.

Waheed, M. A., A. Tasneem, \& G. S. Pervaiz. (2007). Structural Breaks and Unit Roots: Evidence From Pakistani Macroeconomic Time Series, MPRA Paper, No. 1797, (November): $1-18$.

Woodruff, C. (2006). Mexican microenterprise investment and employment: Role of remittances. INTAL-ITD Working Paper 26.

Zivot, E., \& D. Andrews. (1992). Further Evidence of Great Crash, the Oil Price Shock, and Unit Root Hypothesis, Journal of Business and Economic Statistics, 10, 251-270.

\section{Endnotes}

1.Ellerman (2003) reports that Mexican migrant associations send home between US $\$ 5000-\$ 25,000$ per year, while migrant associations from El Salvador send home donations of about US \$10,000 per year. Orozco (2004) identifies at least 2000 HTAs in the U.S., with the highest concentration in southern California and the Chicago Metropolitan area (p. 2). His field work indicates that, on average, Mexican HTAs send around $\$ 10,000$ a year for a variety of rural projects, including health and education, public infrastructure, economic investment, church support, and recreation. He reports that these contributions are quite significant because in rural towns of less than 6000 inhabitants the annual municipal budget for public works is often less than $\$ 50,000$ (p.4).

2. For further detail see Blomstrom and Wolf (op. cit) who find that labor productivity growth in Mexico is positively associated with the degree of foreign concentration in a given industry (pp. 263-284).

3. Investment and FDI data published by the OECD was cross-checked with that found in INEGI and $L a$ 
Economia Mexicana en Cifras, and no significant differences were discerned.

4. For example, Hakkio and Rush (1991) contend that in nearly non-stationary time series "the frequency of observation plays a very minor role" in cointegration [and unit root] analysis because "cointegration is a long-run property, and thus we often need long spans of data to properly test it" (p. 579). They demonstrate this using Monte Carlo simulations for four popular tests. Similarly, Bahmani-Oskooee (1996) observes that in cointegration (and unit root) analysis using annual data over 30 years "is as good as using quarterly data over the same period" (p. 481).

5. The Doldado et al. procedure starts by estimating the most general (unrestricted) model (with a constant and a trend) before moving to the next more restricted model (a constant only), and so on. The order of the lag length was determined by applying both the Akaike Information Criterion (AIC) and the Schwartz Bayesian Criterion (SBC). Between the two criteria, the SBC is more reliable because the AIC is known to be biased towards choosing an over-specified model.

6. A stochastic trend is one where the random component of the series itself, say variable $\mathrm{x}_{\mathrm{t}}$, contributes directly to the long run pattern of the series, either upward or downward. However, in the case of a deterministic trend the deviations from the non-stationary mean over time are quickly corrected. It is also possible for the variable in question to display both a stochastic and deterministic trend process over time. For further details see Charemza and Deadman, (1997, pp. 84-92).

7. The Z-A one-break point unit root test was also performed for the relevant time series in differenced form under the assumption of model $\mathrm{C}$ and the null hypothesis was rejected at the 5 percent level or lower in all cases.

8. Estimates for the labor productivity function are consistent with those for the output function and are available upon request.

9. The public investment variable was assumed to be exogenous because Mexican policymakers abruptly reduced public investment spending in response to the demise of import-substitution industrialization policies as well as external pressure on the part of the IMF and other multilateral institutions (for further details, see Ramirez, 1997).

10. As a confirmatory test, I performed a Gregory and Hansen (1996) cointegration test with endogenously determined level (intercept) shift (CC) and obtained a minimum ADF* stat. $=-5.89$ [break point $=1987]$ which is smaller than the tabulated $1 \%$ critical value $[-5.13(1 \%) ;-4.61(5 \%)$; $-4.34(10 \%)]$ reported by Gregory and Hansen. Thus, the null hypothesis of no cointegration with endogenously determined break is rejected at the 1 percent level of significance. It should be noted that the break date is found by estimating the cointegrating relationship for all possible break dates in the sample period. The Rats program selects the break date where the modified [trimmed] $\mathrm{ADF}^{*}=$ inf $\mathrm{ADF}$ $(\tau)$ test statistic is at its minimum. All estimations were undertaken with Rats 7.3 and are available upon request.

\section{Copyright Disclaimer}

Copyright for this article is retained by the author(s), with first publication rights granted to the journal. 
This is an open-access article distributed under the terms and conditions of the Creative Commons Attribution license (http://creativecommons.org/licenses/by/3.0/). 